\title{
İSVİÇRE MEDENI KANUNU İLE KARŞILAŞTIRMALI OLARAK TÜRK HUKUKUNDA EMEKLIILIKTEN DOĞAN HAKLARIN PAYLAŞTIRILMASI
}

\author{
SHARE THE RIGHTS FROM RETIREMENT IN TURKISH LAW \\ COMPARATIVELY WITH SWISS LAW
}

DOI: 10.21492/inuhfd.349826

Salih POLATER*

\begin{abstract}
Özet
Türk ve İsviçre hukukunda eşler evlilik birliğinin boşanma ile sona ermesi durumunda birbirlerinden maddi tazminat, manevi tazminat, yoksulluk nafakası ve mal rejiminin tasfiyesini talep edebilirler. Her ne kadar Türk Medeni Kanunu ve Türk Medeni Kanunu'nun mehazı olan İsviçre Medeni Kanunu boşanmanın sonuçları yönünden benzer düzenlemeler öngörmüş olsalar dahi, Türk Medeni Kanunu 01.01.2002 yılında yürürlüğe girdikten sonra İsviçre Medeni Kanunu'nda bu kapsamda çok sayıda değişiklik yapılmıştır. $\mathrm{Bu}$ değişikliklerden en önemlilerinden biri 2017 yılında boşanmanın sonuçları arasında öngörülen emeklilik sigortasındaki birikimlerin ve emeklilik maaşlarının paylaştırılmasına yönelik düzenlemelerdir. Türk hukukunda sadece sosyal güvenlik kurumlarının mal rejiminin devamı süresince emeklilik maaşı, emeklilik ikramiyesi, kıdem tazminatı, maluliyet aylığı gibi yaptığı ödemeler edinilmiş mallara katılma rejimi hükümlerine göre paylaştırılabilir. Bunun dışında emeklilik sigortasındaki birikimlerin ve emeklilik maaşlarının paylaştııılmasına yönelik herhangi bir düzenleme yoktur. Bu çalışma ile İsviçre ve Türk hukukunda emeklilikten doğan hakların hangi kapsam ve hangi hükümlere göre paylaştırılabileceği incelenecek ve Türk hukukunda bu konuda ileride yapılabilecek düzenlemelere katkı sağlanmaya çalışılacaktır.
\end{abstract}

Anahtar Kelimeler: Boşanma, boşanmanın sonuçları, emeklilikten doğan haklar, edinilmiş mallara katılma rejimi, İsviçre hukuku

Abstract

In Turkish and Swiss law, spouses may demand material compensation, immaterial compensation, alimony and division of property regime from each other in the case of marriage union ending by divorce. Even if Turkish Civil Code and its source which is Swiss Civil Code predict similar regulations for the results of divorce, there have been amended many significant changes in Swiss Civil Code after Turkey took into force its Civil Code in 01.01.2002. One of the main changes made in 2017 by Switzerland ist to share the retirement insurance savings and retirement benefits. In addition, the

* Yrd. Doç. Dr. Erzincan Üniversitesi İktisadi ve İdari Bilimler Fakültesi spolater@erzincan.edu.tr 
amendments in the Swiss Civil Code in 2017 have made it possible to share the retirement insurance savings and retirement benefits. In Turkish law, in accordance with the regime of participation in acquired property, the payments such as retirement pension, retirement bonus, invalidity pension, severance pay which are made by the social security institutions during the period of the property regime can be shared. There is no regulation related to this in Turkish law. This study aims to examine the scope and provisions of apportionment of the rights arising from retirement in Switzerland and Turkish law and to contribute to future regulations in the Turkish law.

Keywords: Divorce, results of divorce, pension rights, the regime of participation in acquired property, Swiss law

\section{GÍRIŞ}

Evlilik birliği herhangi bir problem olmadan devam ederken, eşlerin evlilik esnasında birlikte veya ayrı ayrı edindiği mallar ve haklar üzerinde nasıl tasarrufta bulunulacakları ve bunların paylaşımı genellikle gündeme gelmemektedir. Ancak evlilikte problemlerin başlaması ile birlikte eşlerin elde ettikleri mallar ve haklar üzerindeki tasarruf yetkilerinin sinırlar1, özellikle de boşanma ile birlikte bunların nasıl paylaşılacağı konusu birçok problemi beraberinde getirmektedir.

Boşanma sonucu hak paylaşımı konusunda öne çıkan problemlerden biri emeklilik dolayısıyla elde edilen hakların paylaşılmasıdır. Evlilik birliğinin giderlerine katılma yükümlülüğünü bir işte çalışarak kazandığı para ile yerine getiren eş, aynı zamanda emekliliğine yönelik tasarruflarda bulunmakta ve geleceğine yönelik önemli bir yatırım yapmaktadır. Ancak evlilik birliğinin giderlerine katılma yükümlülüğünü, asıl olarak ev işlerini yaparak ve çocuklarla ilgilenerek yerine getiren eş ya emekliliğine yönelik herhangi bir tasarrufta bulunamamakta veya diğer eşten daha az bir tasarruf yapabilmektedir. Bu ise evi ve çocukları için daha fazla zaman ayıran eşin menfaatlerini boşanma sonrası olumsuz bir şekilde etkilemektedir. Bu sebeplerle evlilik birliğinin boşanma ile sona ermesi durumunda emeklilik sebebi ile elde edilmiş veya edilecek hangi hakların paylaşılabileceği ve bu paylaşmanın nasıl yapılacağının tespiti büyük bir önem arz etmektedir.

Türk hukukunda evlilik birliğinin boşanma ile sona ermesi durumunda Türk Medeni Kanunu (TMK) eşlerin birbirlerinden maddi tazminat, manevi tazminat, yoksulluk nafakası ve mal rejiminin tasfiyesini talep etme hakkı vermiştir. Eşlerin sahip oldukları malların nasıl 
paylaşılacağı eşler arasında geçerli olan mal rejimine ${ }^{1}$ göre belirlenecektir. Eşlerin emeklilikten doğan haklarının paylaştırılması ise edinilmiş mallara katılma rejimi hükümlerine göre (TMK m. 219/II - b. 2 ve TMK m. 228/II) mümkün olabilecektir. Aşağıda da ele alınacağı üzere, TMK'nın 219/II - b. 2'ye göre “sosyal güvenlik veya sosyal yardım kurum ve kuruluşlarının veya personele yardım amacı ile kurulan sandık ve benzerlerinin yaptığı ödemeler" edinilmiş mal sayıldığı için bu kapsamda emeklilik sebebi ile yapılan ödemeler de kural olarak edinilmiş mal sayılacak ve paylaşmanın konusu olacaktır².

Türk Medeni Kanunu'nun mehazı olan İsviçre hukukunda evlilik birliğinin boşanma ile sona ermesi halinde eşler birbirlerinden, yoksulluk nafakası, maddi ve manevi tazminat ${ }^{3}$ ve ayrıca mal rejiminin tasfiyesini ${ }^{4}$

${ }^{1}$ TMK dört çeşit mal rejimi öngörmüştür. Bunlar, edinilmiş mallara katılma rejimi (TMK m. 218-241), mal ayrılığı rejimi (TMK m. 242-243), paylaşmalı mal ayrılığı rejimi (TMK m. 244-255) ve mal ortaklığı rejimidir (TMK m. 256-281). Eşler TMK m. 202/II.'ye göre mal rejimi sözleşmesiyle Kanunda belirlenen mal rejimlerinden birini kabul edebilirler. Eşler mal rejimi sözleşmesi ile bu mal rejimlerinden birini seçmezlerse TMK m. 202/I.'e göre “yasal mal rejimi” olan edinilmiş mallara katılma rejimini seçmiş sayılacaklardır, GÜMÜŞ, Mustafa Alper, Teori ve Uygulamada Evliliğin Genel Hükümleri ve Mal Rejimleri (TMK m. 185 - 281), Vedat Kitapçılık, İstanbul 2008, s. 218; KILIÇOĞLU, Ahmet M., Aile Hukuku, 2. Bask1, Turhan Kitabevi, İstanbul 2016, s. 300; ŞIPKA, Şükran, Türk Hukukunda Edinilmiş Mallara Katılma Rejimi, 3. Baksı, On İki Levha Yayıncılık, İstanbul 2013, s. 13 vd.; ZEYTiN, Zafer, Edinilmiş Mallara Katılma Rejimi ve Tasfiyesi, 2. Baskı, Seçkin Yayıncılık, Ankara 2008, s. 35 vd.

${ }^{2}$ Bkz. 3. Başlik.

${ }^{3}$ İsviçre hukukunda evlenmenin boşanma ile sona ermesi durumunda eşlerin maddi ve manevi tazminat hakları Türk hukukundan farklı olarak ZGB'de evlenmenin sonuçları arasında sayılmamıştır. Eşler maddi ve manevi tazminat taleplerini İsviçre Borçlar Kanunu'ndaki (Obligationenrecht - OR) maddi ve manevi tazminata ilişkin hükümlere göre talep edebileceklerdir, bkz. SCHWENZER, Ingeborg/BÜCHLER, Andrea, in Famkomm - Scheidung Band I: ZGB, Schwenzer, Ingeborg/Fankhauser, Roland (ed.), 3. Baskı, Stämpfli Verlag, Zürih 2017, Art. 125 ZGB pn. 137 vd.; Karş. CEYLAN, Ebru, Türk ve İsviçre Hukukunda Boşanmanın Hukuki Sonuçları, Galatasaray Üniversitesi Yayınları, İstanbul 2006, S. 73.

${ }^{4}$ İsviçre hukukunda üç çeşit mal rejimi öngörülmüştür. Bunlar; edinilmiş mallara katılma rejimi (ZGB m. 196-220), mal ortaklığı rejimi (ZGB m. 221-246) ve mal ayrılığı rejimidir (ZBG m. 247-251). ZGB m. 181.'e göre eşler bu üç mal rejimden mal ortaklığ 1 veya mal ayrılı̆̆ rejimini seçmedikleri takdirde yasal mal rejimi olan edinilmiş mallara katılma rejimi uygulanacaktır, JUNGO, Alexandra, in CHK - Handkommentar zum Schweizer Privatrecht - Personen- und Familienrecht - Partnerschaftsgesetz -, Breitschmid, Peter/Jungo, Alexandra (ed.), 3. Baskı, Schulthess Verlag, Zürich 2016, Art. 181 ZGB pn. 4 vd. 
talep edebilirler. Türk hukukuyla benzer şekilde mal rejiminin devamı süresince sosyal güvenlik kurumlarının emekliliğe ilişkin yaptığı ödemeler edinilmiş mal sayılacak ve eşler arasında paylaştırılabilecektir (İsviçre Medeni Kanunu - Schweizerisches Zivilgesetzbuch - ZGB m. 197/II - b. 2 ve 207/II $)^{5}$.

Türk hukukundan farklı olarak ZGB'nin ikinci Kitap birinci Kısım dördüncü Bölüm'ün "Boşanmanın Sonuçları”nın düzenlendiği üçüncü Ayrım'ında yer alan ve 2017 yılında yürürlügü giren 122 ila 124e maddelerine göre, evlilik birliğinin boşanma ile sona ermesi durumunda eşler, mesleki emeklilik sigortasındaki ${ }^{6}$ birikimlerinin veya emeklilik maaşlarının paylaştırılmasını da talep edebilirler. Burada özellikle dikkat çeken husus emeklilikten doğan bu hakların paylaştırılmasının eşlerin arasında geçerli olan mal rejiminden bağımsız olarak yapılabilmesidir.

Bu çalışma ile ilk olarak İsviçre hukukunda boşanmanın sonuçları arasında yer alan mesleki emeklilik sigortasındaki birikimlerin ve emeklilik maaşının paylaştırılması konusu incelecektir. Daha sonra her iki hukuk sistemindeki düzenlemelerin benzer olması sebebi ile Türk ve İsviçre hukukuna göre evlilik birliğinin boşanma sebebi ile sona ermesi durumunda emeklilik dolayısıyla yapılan ödemelerin edinilmiş mallara katılma rejimine göre paylaştırılması konusu birlikte ele alınacaktır.

2. ISVIIÇRE HUKUKUNA GÖRE EVLILIĞİN BOŞANMA ÍLE SONA ERMESI HALINNDE MESLEKI EMEKLILIIK SİGORTASINDAKİ BİRIKIMLERIN VE EMEKLILIIK MAAŞININ PAYLAŞTIRILMASI

A. Genel Olarak İsviçre Sosyal Sigortalar Sisteminde Emeklilik

İsviçre hukukunda boşanma sebebi ile emeklilik sigortasındaki birikimlerin ve emeklilik maaşlarının paylaştırılmasının daha iyi anlaşılabilmesi için İsviçre sosyal sigortalar sistemine kısa bir şekilde değinmek faydalı olacaktır. İsviçre sosyal sigortalar sistemi emeklilik için üçlü bir ayrım yapmıştır. Bu üçlü ayrım "üç sütün prensibi” olarakta isimlendirilmektedir. Bunlar: Birinci Sütun: "Yaşl111ı, Dul/Yetim ve Maluliyet Sigortası" (Alters-, Hinterlassenen- und Invalidenversicherung - AHV/IV); ikinci Sütun: "Meslekî Emeklilik Sigortası" (Berufliche

\footnotetext{
${ }^{5}$ Bkz. 3. Başlık.
}

${ }^{6}$ Bkz. 2. Başlık. 
Vorsorge) ve üçüncü Sütun: “Özel Emeklilik Sigortası” (Private Vorsorge $)^{7}$.

Birinci sütunda yer alan AHV/IV-Sigortası temel emeklilik sigortasıdır ve İsviçre'de oturan veya çalışan tüm şahısları kapsar. Bu sigortanın amacı kişilerin emekliliklerinde asgari yaşam giderlerinin karşılanmasını güvence altına almaktır. AHV/IV kapsamında kişilerin prim ödeme zorunluluğu, eğer çalışıyorlarsa 17 yaşını tamamladıktan sonra gelen ocak ayının birinden ve çalışmayan şahıslar için ise 20 yaşını tamamladıktan sonra gelen ocak ayının birinden itibaren başlar. Prim ödeme zorunluluğu, erkeklerde emeklilik yaşı olan 65 ve bayanlarda emeklilik yaşı olan 64'e kadar sürer. Bir kişi çalışıyorsa, ödenecek prim miktarı, işçi ile işveren arasında yarıya bölünür. Kişi eğer çalışmıyorsa veya serbest meslek sahibi ise prim tutarının tümünü kendi karşılamak zorundadır; sosyal yardım alıyorsa, belediye kişi adına söz konusu asgari meblağı yatırır ${ }^{8}$.

Üç sütun sisteminin ikinci sütununu meslekî emeklilik sigortası (Berufliche Vorsorge) oluşturmaktadır. İsviçre'de bir işyerinde çalışan ve yıllık geliri en az 21.150 Frank (2017 yılı itibariyle) olan her kişinin mesleki emeklilik sigortasına bağlı olma zorunluluğu vardır. Ödenilecek prim miktarı işçi ile işveren arasında bölünür. İşverenin katkı payı primin en az yarısı kadardır. Serbest meslek sahiplerinin mesleki emeklilik sigortası yaptırma zorunlulukları yoktur. Meslekî emeklilik sigortası emeklilik müesseseleri (Pensionskasse) tarafından idare edilmektedir. Bir kişi işyerini değiştirdiği zaman mesleki emeklilik sigortası yeni işverenin bağlı bulunduğu emeklilik müessesine geçilir ve önceki emeklilik müessesesinde toplanan emeklilik birikimleri (Austrittsleistung - Çıkış ödeneği), yeni işverenin bağlı bulunduğu emeklilik müessesesine aktarılır.

7 GEIGER, Ingrid Katharina/MICHAELIS, Bettina/PIFKO, Clarisse, Grundlagen der Sozialversicherungen in der Schweiz, 3. Bask1, Compendio Bildungsmedien, Zürich 2012, s. 33 vd.; http://www.bundesfinanzministerium.de/Content/DE/Standardartikel/Themen/Steuern/In ternationales_Steuerrecht/Staatenbezogene_Informationen/Laender_A_Z/Schweiz/201607-27-Schweiz-vorsorgeeinrichtungen-nach-der-zweiten-saeule-der-schweizerischenaltersvorsorge.pdf?_blob=publicationFile $\& \mathrm{v}=1$ (s.e.t. 07.11.2017).

${ }^{8}$ GEIGER/MICHAELIS/PIFKO, $\quad$ s. 35 https://www.sz.ch/public/upload/assets/21088/soziale_sicherheit_in_der_schweiz.pdf (s.e.t. https://www.sem.admin.ch/dam/data/sem/rueckkehr/rueckkehrfoerderung/sozialversiche rung/broschuere-sozialvers-tr.pdf (s.e.t. 07.11.2017). 
Çıkış ödenekleri, sadece iş yeri değişikliğinde değil aynı zamanda iş bırakıldığı zaman ödenecek olan emeklilik birikimlerini de ifade eder. Meslekî emeklilik sigortasında toplanan çıkış ödenekleri, istisnai haller dışında, nakit olarak ödenmez. İşyeri değiştirildiğinde birikimler yeni işverenin bağ 1 bulunduğu emekli müessesesine aktarılır. İş bırakıldığında ise bu ödenek bankada açılacak olan emekliliğe yönelik özel bir mevduat hesabına (Freizügigkeitskonto), özel bir emeklilik poliçesine ilişkin sigorta hesabına (Freizügigkeitspolice) veya özel bir emeklilik müessesesine aktarılır. Nakit ödeme, ancak kişinin İsviçre'yi temelli terk ettiği veya bir işverenin yanında değil de serbest meslek erbabı olarak kendi işini yapmaya başladığında veya çıkış ödeneği, çalışanın yıllık ödediği emeklilik priminden daha az olması durumlarında mümkündür. Nakit ödeme talep eden kişi, evli ise "Freizügigkeitsgesetz"in" (FZG) ${ }^{10}$ 5/II maddesine göre eşinin de yazılı rızası gereklidir ${ }^{11}$.

Üçüncü sütunu oluşturan emeklilik sigortası ise özel emeklilik sigortası sistemidir. Bu emeklilik sigortası kişilerin isteğine bağlı olarak yapılabilmektedir. Kişilerin bu sigortayı yaptırmalarının amacı en son aldıkları maaşın ortalama $\% 60$ ila $\% 75$ 'ine tekabül eden birinci ve ikinci sütundaki emeklilik maaşlarının miktarını artırmaktır $^{12}$.

${ }^{9}$ Bundesgesetz über die Freizügigkeit in der beruflichen Alters-, Hinterlassenen- und Invalidenvorsorge (Freizügigkeitsgesetz, FZG) vom 17. Dezember 1993 (Stand am 1. Oktober 2017).

10 Freizügigkeitsgetz kavramı Kanun'un amacı dikkate alınarak „Emeklilik Hakkı Doğmadan Bağlı Olduğu Emeklilik Müessesinden Ayrılan Kişilerin Haklarına İlişkin Kanun“" şeklinde tercüme edilebilir.

${ }^{11}$ GEIGER/MICHAELIS/PIFKO, $\quad$ s. $\quad 71 \quad$ vd.; https://www.bsv.admin.ch/bsv/de/home/sozialversicherungen/bv/grundlagen-und-

gesetze/grundlagen/sinn-und-zweck.html (s.e.t. 07.11.2017); https://www.ahviv.ch/p/890.d (s.e.t. 07.11.2017);

https://www.google.com.tr/url?sa=t\&rct=j\&q=\&esrc=s\&source=web\&cd=1\&cad=rja\&u act $=8 \&$ ved $=0$ ahUKEwji74D85-

_WAhUKWhoKHTL3AsYQFggmMAA\&url=https\%3A\%2F\%2Fwww.sem.admin.ch\% 2Fdam $\% 2$ Fdata $\% 2$ Fsem $\% 2$ Frueckkehr\%2Frueckkehrfoerderung $\% 2$ Fsozialversicherung $\%$ 2Fbroschuere-sozialvers-tr.pdf\&usg=AOvVaw3GjY_SoNqwdNk-_7qRGKvX (s.e.t. 07.11.2017).

${ }^{12} \mathrm{https}: / /$ www.swisslife.ch/de/gut-zu-wissen/vorsorge-einfach/3-saeulensysstem/drittesaeule.html (s.e.t. 07.11.2017); 2017 tarihinden geçerli olmak üzere sigortalı olan bir kişi herhangi bir Avrupa Birliği ülkesine veya Avrupa Serbest Ticaret Birliği (EFTA) ülkesine taşınırsa kendisine nakit ödeme yapılamaz, bkz. 


\section{B. Emeklilikten Doğan Hakların Paylaştırılmasında Uygulanacak Hükümler}

Boşanma durumunda birinci sütunda yer alan yaşl1lık, dul/yetim ve maluliyet sigortasında (AHV/IV) toplanan birikimler emeklilik sandıkları tarafından eşlerin talepleri üzerine paylaştırılır. Emeklilik sandıkları boşanan eşlerin evlilik süresince ödedikleri primleri yarı yarıya paylaştırır. Ancak primler, eşlere nakit olarak ödenmeyip emeklilik sigortasındaki hesaplarına aktarılır. AHV/IV'ye göre emeklilikten doğan hakların paylaşımı "Federal Yaşlılık, Dul ve Yetim Sigortası Kanunu"na (Bundesgesetz über die Alters- und Hinterlassenenversicherung ${ }^{13}$ ) göre yapıldı ̆̆1 için kamu hukukunun ilgilendirmekte, ZGB'nin kapsamına girmemektedir. Üçüncü sütundan kaynaklanan emekliliğe ilişkin haklar ise eşler arasında geçerli olan mal rejime göre paylaştırılır ${ }^{14}$.

Evliliğin boşanma sebebi ile sona ermesi halinde ZGB m. 122 vd.'lerine göre yapılacak paylaştırma, sadece ikinci sütunda yer alan mesleki emeklilik sigortasından kaynaklanan çıkış ödenekleri ve emeklilik maaşlarına ilişkindir. Ayrılığa hükmedilmesi durumunda çıkış ödenekleri ve emeklilik maaşları ZGB m. 122 vd.'lerine göre paylaştırılamayacaktır ${ }^{15}$. Boşanma sonucunda emeklilikten doğan hakların paylaştırılmasına ilişkin yapılan düzenlemeler ile evlilik birliği içerisinde çocuklarla ve evin diğer işleriyle ilgilenen eşin emekliliğe ilişkin menfaatleri ile çalışmaya daha fazla zaman ayırıp emeklilik için daha fazla tasarruf yapan eşin menfaatlerinin denkleştirilmesi amaçlanmıştır. Zira asıl zamanını ailesi için ayıran eş, ya çalışamaması sebebi ile mesleki emeklilik sigortasına sahip olamamakta veya daha az çalışması sebebi ile daha az emeklilik hakkına sahip olmaktadır ${ }^{16}$.

http://www.edifondo.ch/fileadmin/user_upload/defaultDomain/Barauszahlung/Barausza hlung.pdf (s.e.t. 07.11.2017).

${ }^{13}$ AS 1978 391; BBl 1976 III 1.

${ }^{14}$ Botschaft zur Änderung des Schweizerischen Zivilgesetzbuches (Vorsorgeausgleich bei Scheidung) vom 29. Mai 2013, s. 4905; GEISER, Thomas, Scheidung und das Recht der beruflichen Vorsorge, Was bringt das neue Recht?, AJP/PJA 10/2015, s. 1371-1386, s. 1373 vd.; HAUSHEER, Heinz/GEISER, Thomas/AEBI-MÜLLER, Regina E., Das Familienrecht des Schweizerischen Zivilgesetzbuches, 5. Baskı, Stämpfli Verlag, Bern 2014, s. 153.

${ }^{15}$ Botschaft zur Änderung des Schweizerischen Zivilgesetzbuches (Vorsorgeausgleich bei Scheidung) vom 29. Mai 2013, s. 4905.

${ }^{16}$ HAUSHEER/GEISER/AEBI-MÜLLER, s. 156. 
2017 yılında ZGB'de yapılan değişikliğe kadar eşlerden birinin veya her ikisinin mesleki emeklilik sigortasına sahip olmas1 ve henüz emekli olmamaları durumunda sadece eşlerin çıkış ödenekleri, yarı yarıya paylaştırılabiliyordu. Eşler, boşanmadan önce emekli oldukları takdirde çıkış ödenekleri üzerinde herhangi bir hak iddia edemiyorlard ${ }^{17} .2017$ yılında yapılan değişiklikle boşanma sonucu mesleki emeklilik sigortasına ilişkin hakların paylaştırılmasına yönelik olarak eşlerin emekli olmadan önce boşanmaları, eşlerin emeklilik yaşını doldurmadan malullük aylığı bağlandıktan sonra boşanmaları ve eşlerin emeklilik yaşını doldurup emekli olduktan sonra boşanmaları durumları dikkate alınarak çıkış ödenekleri ve emeklilik maaşlarının paylaşılmasına yönelik farklı düzenlemeler öngörülmüştür ${ }^{18}$. Ayrıca getirilen yeni düzenlemeler mahkemeye, somut olayın özelliklerine göre, emeklilikten doğan bu hakların yarı yarıya veya daha az yahut daha fazla paylaştırılmasına yönelik geniş bir takdir yetkisi de vermiştir ${ }^{19}$.

\section{Eşlerin Emekli Olmadan Boşanmaları Durumunda Yapılacak Paylaşım}

Boşanma davalarının birçoğunda eşlerden en az biri, aktif olarak çalışmakta ve mesleki emeklilik sigortasına bağlı olmaktadır. Bu sebeple eşlerin emekli olmadan önce boşanmaları halinde emeklilik sigortasındaki birikimlerinin (Austrittsleistung - Çıkış Ödeneği) paylaştırılması emeklilikten doğan hakların paylaşılması kapsamında uygulamada en sık rastlanılan durumlardan biridir $^{20}$. ZGB m. 122'ye göre:

"Evliliğin başlangıcından boşanma davasının açıldığı tarihe kadar mesleki emeklilik sigortası kapsamında edinilen haklar boşanma sırasında denkleştirilir".

Madde hükmüne göre bir eş, diğer eşin mesleki emeklilik sigortasından sadece evliliğin başlangıcından boşanma davası açıldığ 1 tarihe kadar elde edilmiş olan hakları talep edebilir. Bu sebeple eşlerden birinin boşanma davası açıldıktan sonra emekli olması veya emeklilik

17 Ayrıntılı bilgi için bkz. GEISER, Thomas, Gestaltungsmöglichkeiten beim Vorsorgeausgleich, Zeitschrift des Bernischen Juristenvereins. - Bern. - Jg. 153 (2017), H. 1, S. 1-24, s. 1 vd.

${ }^{18}$ GEISER, Gestaltungsmöglichkeiten beim Vorsorgeausgleich, s. 5; GRÜTTER, Myriam, Der neue Vorsorgeausgleich im Überblick, FamPra.ch 2017, S. 127, s. 127-156, s. 127 vd.

${ }^{19}$ Bkz. 2. E., G., H. Başlıkları.

${ }^{20}$ GEISER, Scheidung und das Recht der beruflichen Vorsorge, s. 1378. 
durumunda değişiklik olması diğer eşin talep edebileceği miktarı etkilemeyecektir ${ }^{21}$. 2017 yılında yapılan değişiklikten önce boşanma kararının kesinleşmesine kadar biriken emeklilik keseneklerinin paylaştırılması öngörülmüştü. Ancak bu düzenleme, emeklilik keseneklerinden hak talep edecek eşin daha fazla pay alabilmek maksadıyla boşanma davasının uzaması için adımlar atmasına sebep olmakta ve ayrıca paylaştırılacak çıkış ödeneklerinin hesaplanmasına ilişkin problemlere sebep olmaktaydı. Yeni getirilen düzenleme ile bu tür problemlerin önüne geçilmek istenmiştir ${ }^{22}$.

ZGB m. 123'e göre eşlerin emekli olmadan önce boşanmaları halinde çıkış ödenekleri yarı yarıya paylaştırılır. Ancak eşlerden birinin boşanma davasından önce emekli olması durumunda bu eşin çıkış ödeneği ZGB m. 123'e göre paylaştırılamaz. Zira bu durumda çıkış ödeneği değil, sadece emeklilik maaşı ve ZGB m. 124a'ya göre emeklilik maaşının paylaştırılması söz konusu olacaktır ${ }^{23}$. Her iki eşin mesleki emeklilik sigortasının bulunması durumunda paylaştırmaya konu olacak miktar ZGB m. 124c'e göre eşlerin çıkış ödenekleri arasındaki farktır ${ }^{24}$.

Yukarıda açıklandığı üzere, çıkış ödenekleri kişiye istisnai haller dışında nakit olarak ödenmez ${ }^{25}$. Bu sebeple eşler arasında yapılan bu paylaştırmada kural olarak eşlere nakit para ödemesi yapılmamakta; çıkış ödeneğinden pay alan eş çalışıyor ise ödenecek miktar, onun mesleki emeklilik müessesindeki hesabına aktarılmaktadır. Ancak eşlerden birinin kendi işini yapmaya başlaması veya İsviçre'yi temelli terk etmesi halinde nakit ödeme yapılabilir ${ }^{26}$. Eşlerden sadece biri çalışıyor ise çalışmayan ve mesleki emeklilik sigortası olmayan eşe ödenmesi gereken miktar açılacak emeklilik mevduat hesabına (Freizügigkeitskonto) veya bir sigorta şirketinin emekliliğe yönelik sigorta hesabına (Freizügigkeitspolice) $\operatorname{aktar1}_{12}{ }^{27}$.

${ }^{21}$ GEISER, Gestaltungsmöglichkeiten beim Vorsorgeausgleich, s. 6; GEISER, Scheidung und das Recht der beruflichen Vorsorge, s. 1373; GRÜTTER, Der neue Vorsorgeausgleich s. 129, 133.

${ }^{22}$ Botschaft zur Änderung des Schweizerischen Zivilgesetzbuches, s. 4905 vd.

${ }^{23}$ GRÜTTER, s. 133; Bkz. 2. E. Başlık.

${ }^{24}$ GEISER, Gestaltungsmöglichkeiten beim Vorsorgeausgleich, s. $21 \mathrm{vd}$.

${ }^{25}$ Bkz. 2. A Başlik.

${ }^{26}$ GEISER, Scheidung und das Recht der beruflichen Vorsorge s. 1379.

27 GEISER, Scheidung und das Recht der beruflichen Vorsorge s. 1379; HAUSHEER/GEISER/AEBI-MÜLLER, s. 159. 


\section{Emeklilik Yaşını Doldurmadan Malullük Aylığı Bağlanması Durumunda Paylaşım}

Kendisine emeklilik yaşını doldurmadan malullük aylığı bağlanan kişilerin de kural olarak çıkış ödenekleri üzerinde tasarruf imkânı vardır. $\mathrm{Bu}$ kişilerin çıkış ödenekleri tekrar çalışabilmeleri durumu dikkate alınarak emeklilik kasaları tarafından işletilirler. FZG m. 2/ ${ }^{\text {ter }}$ e göre, kendisine maluliyet aylığı bağlanan kişi çıkış ödeneği üzerinde ancak maluliyet durumunun sona ermesi halinde tasarrufta bulunabilit ${ }^{28}$. Bu kurala göre boşanma davası sırasında maluliyet durumu sona ermemiş olan eşin çıkış ödeneği üzerinde tasarrufta bulunulamaması ve paylaşmaya da konu olamaması gereklidir. Ancak ZGB m. 124 "varsayımsal çıkıș ödeneği" müessesini öngörmüştür. Bu düzenlemeye göre, maluliyet aylığ 1 bağlanan kişinin çıkış ödeneği üzerinde her ne kadar tasarruf imkânı bulunmasa da boşanma davasının açıldığı tarihte maluliyet durumunun sona erdiği varsayılarak boşanma davası açılana kadar biriken çıkış ödeneği paylaştırmanın konusu olur. Bu paylaşım ZGB m. 123'te öngörülen yarı yarıya paylaştırmayla aynı kurallara tabidir. Ancak burada sadece çıkış ödeneği paylaştırmanın konusu olup maluliyet aylığı eşler arasında paylaştırılamaz ${ }^{29}$.

\section{E. Emeklilik Yaşının Doldurulmasından Sonra Malulen Emekli Olunması veya Yaşlıık Aylığı Bağlanması Durumunda Paylaşım}

İsviçre hukukunda çıkış ödeneği, sadece emekli olunmadan önce ödenebildiği için emekli olduktan sonra kural olarak toplu bir ödeme yapılmamaktadır; emeklilik sebebi ile yapılan birikimler dolayısıyla sadece emeklilik maaşı ödenmektedir. Bu sebeple emekli olduktan sonra evliliğin boşanma ile sona ermesi durumunda emeklilikten doğan haklar bakımından sadece emeklilik maaşının paylaştırılması söz konusu olabilecektir ${ }^{30}$.

ZGB m. 124a/I'e göre, eşlerden birinin boşanma davası açılmadan önce ve emeklilik yaşının doldurulmasından sonra malulen emekli olması veya yaşlılık aylığı bağlanmış olması durumunda emeklilik maaşı

${ }^{28}$ GRÜTTER, s. 133 vd.; Botschaft zur Änderung des Schweizerischen Zivilgesetzbuches, s. 4907.

${ }^{29}$ GEISER, Gestaltungsmöglichkeiten beim Vorsorgeausgleich, s. 7; GEISER, Scheidung und das Recht der beruflichen Vorsorge, s. 1380; GRÜTTER, s. 134.

${ }^{30}$ Botschaft zur Änderung des Schweizerischen Zivilgesetzbuches, s. 4910. 
mahkemenin takdirine göre paylaştırılır. Emeklilik maaşı paylaştırılan eşin ölmesi veya emeklilik maaşından hak kazanan tarafın evlenmesi durumunda, kendisine emeklilik maaşından belli bir pay verilen eşin bu hakk1, yoksulluk nafakasından farklı olarak (ZGB m. 130), sona ermemektedir. Böylece emeklilik maaşı üzerinde belli bir oranda hak sahibi olan eşe ömür boyu maddi bir güvence sağlanmış olmaktadır ${ }^{31}$.

ZGB m. 124a/I'e göre bir eşin emeklilik maaşının paylaştırmaya konu olabilmesi için boşanma davası açılmadan önce emekli olması gereklidir. Bu sebeple, yukarıda da belirtildiği üzere, eşin boşanma davası açılmadan önce emeklilik yaşını doldurmasına rağmen emekli olmaması durumunda emeklilik maaşı değil ZGB m. 123.'e göre sadece çıkış ödeneği paylaştırılacaktır. Ayrıca emeklilik maaşı paylaştırılmaya konu olan eşin boşanma davası açılmadan önce emekliliğe ilişkin haklarını, istisnai de olsa, nakit olarak alması durumunda ${ }^{32}$ ZGB m. 124a.' ya göre bir paylaşım yapılmaz. Burada eşler arasındaki mal rejimine göre bir paylaştırma yapılır ${ }^{33}$.

ZGB m. 124c'ye göre her iki eşin mesleki emeklilik sigortasının bulunması durumunda paylaştırmaya konu olacak miktar, eşlerin emeklilik maaşları birbirinden mahsup edildikten sonra ortaya çıkan farktır. Eşlerden birinin emekli olması ve diğerinin ise çalışıyor olması durumunda çıkış ödeneği ve emeklilik maaşlarının birbirinden mahsup edilebilmesi, eşlerin ve bağlı bulundukları emeklilik müesseselerinin buna razı olmaları şartına bağlıdır ${ }^{34}$.

Mahkeme emeklilik maaşına yönelik paylaştırmayı yaparken çıkış ödeneklerinin paylaştırılmasında olduğu gibi yarı yarıya bir paylaştırma değil ZGB m. 124a./I’e göre, özellikle evliliğin süresine ve eşlerin bakım ihtiyaçlarına göre takdir edeceği bir paylaştırma yapar. Burada mahkeme; ayrıca eşlerin yaşlarını, emekliliğin başlangıç zamanını ve eşler arasında paylaştırmaya etki edebilecek diğer hususları da dikkate alabilir ${ }^{35}$. Eşlerin evli kaldıkları süre ne kadar uzunsa eşlerin emeklilik maaşlarındaki paylaşılacak oran daha fazla olacaktır. Kısa süren evliliklerde ise

\footnotetext{
${ }^{31}$ GEISER, Scheidung und das Recht der beruflichen Vorsorge, s. 1380 vd.; Botschaft zur Änderung des Schweizerischen Zivilgesetzbuches, s. 4910.

${ }^{32}$ Bkz. 3. Başlik.

${ }^{33}$ GRÜTTER, s. 144.

${ }^{34}$ GEISER, Gestaltungsmöglichkeiten beim Vorsorgeausgleich, s. 21 vd.

35 Botschaft zur Änderung des Schweizerischen, s. 4911.
} 
emeklilik maaşının tamamının yarıya paylaştırılması yerine daha küçük bir oranda paylaştırma yapılabilecektir ${ }^{36}$. Emeklilik maş̧ının paylaştııılmasında mahkeme eşlerin içinde bulundukları ekonomik durumu da dikkate alacaktır. Bu sebeple mahkeme emeklilik maaşına ilişkin paylaştırmayı yapmadan önce ilk olarak eşler arasındaki mal rejimini tasfiye edecektir. Tasfiye sonrasında eşlerin ekonomik durumları belli bir ölçüde belirlendikten sonra emeklilik maaşının nasıl paylaşılacağına karar verilecektir. Emeklilik maaşının paylaşılmasına ilişkin karar verdikten sonra da yoksulluk nafakası tespit edilecektir ${ }^{37}$.

Kanun gerekçesinde ${ }^{38}$ söz konusu paylaştırmanın nasıl yapılacağına ilişkin örnek bir olay ve ayrıca emeklilik maaşından diğer eşe kalacak orana ilişkin bir tablo ${ }^{39}$ yer almaktadır. Ancak Kanun gerekçesinde yer alan bu tablo ve örnek olay sadece yol gösterici mahiyette olup bir bağlayıcılığı bulunmamaktadır ${ }^{40}$.

Örnek olayda eşlerin ortalama 40 y1l çalıştıktan sonra emekli oldukları varsayılmıştır. Tüm emeklilik süreci $\% 100$ olduğu için her yılın tüm emeklilik süresi içindeki oranı $\% 100: 40=\% 2,5^{\prime}$ tur.

$\mathrm{Bu}$ örnekte eşlerden biri evlenirken 35 yaşında, emekliliğinin başladığı tarihte 60 yaşında, boşanma davasının açıldığı tarihte ise 70 yaşındadır. Verilen bu bilgilerin tablodaki karşıllğı \%82,9'dur. Emekliliğin başlangıcından boşanmaya kadar geçen süre 10 yıldır. Dolayısıyla $10 \times 2,5=25$, sonucu belirlemek için $25+82,9=\% 107,9$ 'dur. Bu da göstermektedir ki bu eşin alacağı maaşın hepsi paylaşmanın konusu olacaktır. Diğer eş ise evlenirken 45 yaşında, emekliliğinin başladığ tarihte 67 yaşında ve boşanma davasının açıldığı tarihte 75 yaşındadır. Verilen bu bilgilerin tablodaki karşıllığ $\%$ 068,3'tür. Emekliliğin başlangıcından boşanmaya kadar geçen süre 8 yıldır. Dolayısıyla $8 \times 2,5=20$, sonucu belirlemek için $20+68,3=\% 88,3$ 'tür. $\mathrm{Bu}$ da göstermektedir ki bu eşin alacağı maaşın \%88,3'ü paylaşmanın konusu olacaktır ${ }^{41}$.

\footnotetext{
${ }^{36}$ GRÜTTER, s. 147.

${ }^{37}$ BGE 130 III 537 E. 4; Botschaft zur Änderung des Schweizerischen, s. 4911.

${ }^{38}$ Botschaft zur Änderung des Schweizerischen, s. $4955 \mathrm{vd}$.

${ }^{39}$ Bkz. İlgili tablo makalenin en sonunda yer almaktadır.

${ }^{40}$ GEISER, Gestaltungsmöglichkeiten beim Vorsorgeausgleich, s. 11.

${ }^{41}$ Botschaft zur Änderung des Schweizerischen, s. 4956.
} 


\section{F. Emeklilikten Doğan Hakların Paylaştırılmasından Feragat}

ZGB m. 124b/I'e göre eşler, çıkış ödeneklerinin yarı yarıya paylaştırılmasından veya emeklilik maaşlarının paylaştırılmasından kısmen veya tamamen feragat hususunda anlaşabilirler. Eşlerin birbirlerinin emeklilik haklarından feragat edebilmeleri, ileride geçimlerini sağlamaya yönelik uygun bir emeklilik güvencesine sahip olmaları halinde mümkündür. Burada geçerli bir feragatten bahsedilebilmesi için vazgeçen eşin, geçimini herhangi bir mal varlığ değerinden sağlayabilmesi yeterli olmayıp uygun bir emeklilik imkânına sahip olması gereklidir. Bu sebeple mal rejiminin tasfiyesi sonucu, eșin elde edeceği mal varlığ veya eşin sahip olduğu diğer gelirler, feragatin mahkeme tarafından kabul edilmesi için yeterli değildir ${ }^{42}$.

Eşlerin emeklilikten doğan hakların paylaştırılmasından feragat edebilmesi için hali hazırda bir emeklilik maaşına sahip olmaları şart olmayıp geçimlerini sağlayacak bir emeklilik maaşına sahip olabileceklerine yönelik somut olguların varlı̆̆ 1 yeterlidir. Yaşları genç olan kişilerin daha uzun yıllar çalışıp yaşlılıkları için daha uygun bir emeklilik imkânı sağlamalanı kuvvetle muhtemeldir. Bu sebeple bu kişilerin ileride geçimlerini sağlamaya yönelik uygun bir emeklilik güvencesine sahip oldukları kural olarak kabul edilebilir. Yaşlı kişilerin ise geçimleri için uygun bir emeklilik imkânına sahip olup olmadıkları boşanmaya kadar emeklilik için yaptıkları tasarruflara göre tespit edilecektir ${ }^{43}$.

Geçerli bir feragatin varlığ için feragat eden eşin sadece rızasını açıklaması yeterli olmayıp ayrıca haklarından neden feragat ettiğini ve kendi geçimini sağlayacak emeklilik imkânları hakkında mahkemeyi bilgilendirmelidir. Mahkeme rızanın varlığını ve feragat eden eşin yeterli emeklilik güvencesine sahip olup olmadığını re'sen inceleyerek feragate ilişkin yapılan anlaşmanın geçerliliğine karar verir ${ }^{44}$.

42 GEISER, Gestaltungsmöglichkeiten beim Vorsorgeausgleich, s. 14; karş. HAUSHEER/GEISER/AEBI-MÜLLER, s. 157 vd.

${ }^{43}$ GRÜTTER, s. 137.

44 SCHWANDER, Ivo, in ZGB Kommentar Schweizerisches Zivilgesetzbuch, Kostkiewicz, Jolanta Kren/Wolf, Stephan/Amstutz, Marc/Fankhauser, Roland (ed.), 3. Bask1, Orell Füssli Verlag, Zürich 2016, Art. 197 ZGB pn. 1, 2; Botschaft zur Änderung des Schweizerischen Zivilgesetzbuches, s. $4915 \mathrm{vd}$. 


\section{G. Yarı Yarıya Paylaştırmadan Daha Az Bir Paylaştırmanın Yapılması}

ZGB m. 124b/II'ye göre, mahkeme önemli sebeplerin bulunmas1 halinde hak sahibi eşe çıkış ödeneğinin yarısından azının verilmesine hükmedebileceği gibi paylaştırmanın yapılmasını da tamamen reddedebilir. ZGB m. 124a, emeklilik maaşlarının paylaştırılmasında mahkemeye geniş bir takdir hakkı tanındığı için ZGB m. 124b/II, emeklilik maaşlarının paylaştııılmasında değil sadece çıkış ödeneklerinin paylaşılmasında uygulanır ${ }^{45}$.

ZGB m. 124b/II, önemli sebeplerin varlığını tespit etmek için dikkate alınması gereken hususların ne olduğunu örnek olarak saymıştır. Buna göre, mal rejiminin tasfiyesi sonucu eşlerin paylarına düşen miktar, boşanmadan sonra eşlerin içinde bulunacakları ekonomik durum yahut eşler arasındaki yaş farkı ve dolayısıyla eşlerin bakım ihtiyaçları dikkate alındığında yarı yarıya paylaşım hakkaniyete aykırı olmamalıdır. Ancak mahkeme yarı yarıya paylaştırmadan daha az bir paylaştırmaya hükmederken boşanmaya neden olan olaylarda eşlerin kusur oranını kural olarak dikkate almaz ${ }^{46}$. Önemli sebeplerin varlı̆̆ına ilişkin şu örnekler verilebilir:

- Eşlerden birinin malvarlığından harcamalar yaparak diğerinin mesleki eğitimini desteklemesi ve diğer eşin daha iyi bir emeklilik imkânına kavuşması;

- Bir işyerinde çalışan eşin bürüt maaşından emekliliğe yönelik kesintilerin yapılması sebebi ile net maaşının düşük olması ve dolayısıyla daha az malvarlığına sahip olması; ancak emekliliğe ilişkin haklarının daha fazla olması; buna karşıllk serbest meslek icra eden eşin mesleki emeklilik için pirim ödemeyip daha fazla malvarlığına sahip olması ${ }^{47}$.

\section{H. Yarı Yarıya Paylaştırmadan Daha Fazla Bir Paylaştırmanın Yapılması}

ZGB m. 124b/III'e göre, mahkeme diğer eşin çıkış ödeneği üzerinde hak sahibi olan eşe çıkış ödeneğinin yarısından fazlasının verilmesine hükmedebilir. Ancak bunun için hak sahibi eşin boşanmadan sonra ortak çocuklara bakmak ile yükümlü olması ve daha fazla çıkış

${ }^{45}$ GEISER, Gestaltungsmöglichkeiten beim Vorsorgeausgleich, s. 13; GRÜTTER, s. 136;

Botschaft zur Änderung des Schweizerischen Zivilgesetzbuches, s. 4917.

${ }^{46}$ GEISER, Gestaltungsmöglichkeiten beim Vorsorgeausgleich, s. 15.

${ }^{47}$ Botschaft zur Änderung des Schweizerischen Zivilgesetzbuches, s. 4917. 
ödeneği ödeyecek olan eşin ise kendi geçimini sağlayacak olan yaşl1lık veya maluliyet aylığını aşan bir güvenceye sahip olması gereklidir. Yapılan bu düzenleme ile çocukların bakım yükümlülüğü altında olan eşin bir meslek edinemeyecek veya mesleği için eskisinden daha az zaman ayırabilecek olması sebebi ile daha düşük emeklilik maaşı alması durumu dikkate alınarak söz konusu hak kayıpları belli bir ölçüde denkleştirilmeye çalışılmıştır ${ }^{48}$.

\section{Mesleki Emeklilik Sigortasındaki Birikimler Dışındaki Malvarlığı İle Paylaştırma}

ZGB m. $124 \mathrm{~d}$ ve $124 \mathrm{e}$, mesleki emeklilik haklarına ilişkin paylaşımın mesleki emeklilik sigortasındaki birikimlerle değil, diğer malvarlığı değerleri ile yapılabilmesini mümkün kılmıştır. ZGB m. 124d'ye göre, çıkış ödeneği veya emeklilik maaşının paylaşımının mesleki emeklilik sigortasındaki birikimlerden yapılması durumunda emekliliğine ilişkin menfaatleri önemli ölçüde zarara uğrayacak olan eş, paylaşmanın mesleki emekliliğindeki birikimler dışında sahip olduğu diğer malvarlığı değerleri ile yapılmasını talep edebilir. Paylaştırmanın mesleki emeklilik sigortası dışındaki malvarlı̆̆ değerleri ile yapılmasına karar verilirken diğer eşin emeklilik hakları üzerinde hak sahibi olan eşin menfaatlerinin de olumsuz bir şekilde etkilememesi gereklidir. Bu duruma örnek olarak, hak sahibi eşin İsviçre'yi terk edeceği için nakit paraya ihtiyaç duyması ve İsviçre'de emeklilik hakkı elde etmesinin kendisi için önemli olmaması ve diğer eşin emekliliğe ilişkin haklarının önemli ölçüde zarara uğraması durumu gösterilebilir. Burada yükümlü eşin paylaştırmada emeklilik maaşının yerine, paylaştırmaya konu olacak miktarı, diğer malvarlığı değerleri ile karşılamak istemesi durumunda ne hak sahibi eşin ne de yükümlü olan eşin emekliliğine ilişkin menfaatleri zarara uğrayacaktır ${ }^{49}$.

ZGB m. 124e'ye göre, çıkış ödeneği veya emeklilik maaşına ilişkin paylaştırmanın emeklilik sigortasındaki birikimler vasıtasıyla yapılması mümkün değilse yükümlü olan eş, hak sahibi eşe uygun bir tazminatı nakit olarak veya taksitler halinde ödemekle yükümlüdür. Buna göre, örneğin yükümlü olan eş İsviçre'yi kesin olarak terk edeceği veya çalıştığı işi bırakıp serbest meslek yapmaya başlayacağı için çıkış ödeneğinin

48 GEISER, Gestaltungsmöglichkeiten beim Vorsorgeausgleich, s. 15; Botschaft zur Änderung des Schweizerischen Zivilgesetzbuches, s. 4919.

${ }^{49}$ GRÜTTER, s. 149 vd.; Botschaft zur Änderung des Schweizerischen, s. 4921. 
hepsini nakit olarak almışsa yahut emekliliğe ilişkin tasarruflarının asıl kısmı yurt dışında bulunuyorsa, emeklilik sigortasındaki birikimler vasıtasıyla paylaşma mümkün olmayacağı için hak sahibi olan eşe uygun bir tazminat ödemekle yükümlü olacaktır ${ }^{50}$.

\section{TÜRK VE İSVIÇRE HUKUKUNA GÖRE EVLILIIĞIN BOŞANMA ILE SONA ERMESİ HALINDE EMEKLIILIKTEN DOĞAN HAKLARIN EDINILMIŞ MALLARA KATILMA REJIMINE GÖRE PAYLAŞTIRILMASI}

\section{A. Genel Olarak}

Türk hukukunda boşanmanın sonuçları arasında İsviçre hukukundaki şekliyle emeklilik sigortasındaki birikimlerin ve ödenecek olan emeklilik maaşının paylaştııılmasına ilişsin herhangi bir düzenleme yer almamaktadır. Buna karşın, eşler arasında edinilmiş mallara katılma rejimin geçerli olduğu durumlarda mal rejiminin devamı süresince sosyal güvenlik kurumlarının emeklilik sebebi ile yaptığı ödemeler, TMK m. 219 ve 228 'e göre paylaştırılabilecektir. Yukarıda açıklandığı üzere, İsviçre hukukunda ise emeklilik sigortasındaki birikimlerin (çıkış ödeneklerinin) ve ödenecek olan emeklilik maaşının paylaştırılması eşler arasındaki mal rejiminden bağımsız olarak yapılabilecekken, mal rejimi süresince sosyal güvenlik kurumlarınca emeklilik sebebi ile yapılan ödemeler, Türk hukukundaki şekliyle edinilmiş mallara katılma rejimine göre (ZGB m. 197/II-b. 2 ve 207/II) paylaştırılacaktır.

TMK m. 219/I - ZGB m. 197/I'e göre edinilmiş mal, eşlerin mal rejiminin devamı süresince karşılı̆̆ını vererek elde ettiği malvarlığ değerleridir. Buna göre bir malın edinilmiş mal olarak kabul edilebilmesi için mal rejiminin devamı süresince ve karşıllı̆ı verilerek edinilmesi gereklidir $^{51}$. Ayrıca eşlerin edindikleri mallar, TMK'da - ZGB'de kişisel mal olarak kabul edilen mallar arasında yer almamalıdır. Zira TMK m. 220 - ZGB m. 198'de kişisel mallar arasında yer alan "eşlerden birinin yalnız kişisel kullanımına yarayan eşya"lar, mal rejimi süresince ve karşılığ 1 verilerek elde edinilmiş olsa dahi TMK ve ZGB bu malları kişisel

${ }^{50}$ GEISER, Gestaltungsmöglichkeiten beim Vorsorgeausgleich, s. 19 vd.; Botschaft zur Änderung des Schweizerischen Zivilgesetzbuches, s. 4922.

${ }^{51}$ KILIÇOĞLU, Ahmet, Katk1-Katılma Alacağ1, 5. Bask1, Turhan Kitabevi, Ankara 2014, s. 8 vd.; ŞIPKA, s. 92 vd.; ZEYTİN, s. 94 vd. 
mal olarak kabul etmiştir ${ }^{52}$. TMK m. 219/II - ZGB m. 197/II'de edinilmiş mallar örnek olarak sayılmıştır. Buna göre edinilmiş mallar özellikle eşlerin çalışmalarının karşılığı olan edinimler, sosyal güvenlik veya sosyal yardım kurum ve kuruluşlarının veya personele yardım amacı ile kurulan sandik ve benzerlerinin yaptığı ödemeler, çalışma gücünün kaybı nedeniyle ödenen tazminatlar, kişisel mallarının gelirleri, edinilmiş malların yerine geçen değerlerdir. Yapılan bu sayım sınırlayıcı nitelikte olmadığı için sayılan bu mallar dışında TMK m. 219/I - ZGB m. 197/I'deki şartlara sahip diğer mallar da edilmiş mal olarak kabul edilebilecektir ${ }^{53}$.

\section{B. Emeklilik Dolayısıyla Yapılan Ödemelerin Paylaştırılması}

TMK m. 219/II.-b.2 - ZGB m. 197/II-b.2'ye göre, sosyal güvenlik veya sosyal yardım kurum ve kuruluşlarının veya personele yardım amacı ile kurulan sandıkların yaptığı ödemeler edinilmiş mal sayılmaktadır. Böylece çalışma karşılı̆̆ 1 olan edimleri edinilmiş mal olarak kabul eden kanun koyucu, aynı zamanda onun yerine yapılan ödemeleri de edinilmiş mal olarak kabul etmektedir ${ }^{54}$. Yapilan bu ödemelerin TMK m. 219/II-b.2 - ZGB m. 197/II-b.2 kapsamında edinilmiş mal olarak kabul edilebilmesi için ödemelerin yaşlılık, ölüm, sakatlık, hastalık, kaza veya işsizlik gibi sosyal riskler sebebi ile kamu otoritesi kullanan kurum veya kuruluşlarca gerçekleştirilmesi gereklidir. Bu sebeple sosyal güvenlik kurumlarının yaptıkları emeklilik ödemeleri veya maluliyet aylı̆̆

52 ACABEY, Mehmet Beşir "Edinilmiş Mallara Katılma Rejiminde Mal Grupları-İspat Kuralları ve Eşlerden Paylı Mülkiyeti Altındaki Mallara İlişkin Düzenlemeler”, Dokuz Eylül Üniversitesi Hukuk Fakültesi Dergisi, 9, 2007, s. 497; GÜMÜŞ, s. 253; NUSPLIGER, Isabelle, in ZGB Kommentar Schweizerisches Zivilgesetzbuch, Kostkiewicz, Jolanta Kren/Wolf, Stephan/Amstutz, Marc/Fankhauser, Roland (ed.), 3. Bask1, Orell Füssli Verlag, Zürich 2016, Art. 197 ZGB pn. 2; STECK, Daniel, in FamKomm - Scheidung Band I: ZGB, Ingeborg, Schwenzer/Roland, Fankhauser (Edt.), 3. Bask1, Stämpfli Verlag, Bern 2017, Art. 197 ZGB pn. 5.

${ }^{53}$ ACABEY, s. 501; GÜMÜŞ, s. 254, 264; HAUSHEER/GEISER/AEBI-MÜLLER, s. 229 vd.; KILIÇOĞLU, Aile Hukuku, s. 339.

${ }^{54}$ ACAR, Faruk, Aile Hukukumuzda Aile Konutu Mal Rejimleri ve Eşin Yasal Miras Pay1, 3. Bask1, Seçkin Yayıncılık, Ankara 2016, s. 212 vd.; GÜMÜŞ, s. 258; HAUSHEER/GEISER/AEBI-MÜLLER, s. 233; SARI, Suat, Evlilik Birliğinde Yasal Mal Rejimi Olarak Edinilmiş Mallara Katılma Rejimi, Beşir Kitabevi, İstanbul 2017, s. 153 vd.; ŞIPKA, s. 97; ZEYTIN, s. 102. 
kapsamda değerlendirilebilir ${ }^{55}$. Ancak özel hukuk sözleşmesine dayanan özel emeklilik sigortası kapsamında yapılan ödemeler TMK m. 219/II-b.2 - ZGB m. 197/II-b.2 kapsamında değerlendirilemeyecektir. Özel emeklilik sigortalarından doğan hakların edinilmiş mal sayılıp sayılmayacağ 1 TMK m. 219/II.-b.5 - ZGB m. 197/II-b.5'e ve TMK m. 220/II.-b.4 - ZGB m. 198/II-b.4'e göre ikame ilkesi kapsamında belirlenecektir. $\mathrm{Bu}$ sebeple emekliliğe ilişkin hakların dayanağını oluşturan primlerin kişisel mallardan $\mathrm{m} 1$, yoksa edinilmiş mallardan $\mathrm{m} 1$ karşılandığı tespit edilmeli ve buna göre bir tasfiye yapılmalıdır ${ }^{56}$.

Sosyal güvenlik kurumlarının emekliliğe ilişkin yaptığı ödemelerin edilmiş mal sayılabilmesi için ödemelerin mal rejiminin devamı süresince yapılması gereklidir. $\mathrm{Bu}$ sebeple mal rejiminin devamı süresince sosyal güvenlik kurumlarınca emekliliğe ilişkin yapılan toptan ödemeler veya elde edilen emeklilik maaşlarından yapılan tasarruflar edinilmiş mal sayılacaktır. Mal rejimi, ölüm sebebi ile sona ererse sosyal güvenlik kurumlarınca yapılacak ödemeler edinilmiş mal sayılmayacaktır. Zira bu ödemeler mal rejimi sırasında değil sona erdikten sonra yapılmaktadır ${ }^{57}$.

Mal rejiminin devamı sırasında elde edilmiş bir malvarlı̆̆g olmadan, bir başka ifade ile eşlerden birine sosyal güvenlik ve yardım kurumlarınca yapılmış bir ödeme, malvarlığına giren bir değer bulunmadan ileride elde edilebilecek malvarlığının değeri (beklemece $=$ beklenen ileride ödenebilen haklar - Anwartschaftsrechte) üzerinde tasfiye yapılmas1

55 KILIÇOĞLU, Ahmet M., Edinilmiş Mallara Katilma Rejimi (Tartışmalar-Örnekli Açıklamalar-Formüller-Tablolar-İlgili Yasa Metinleri), 2. Baskı, Turhan Kitabevi, İstanbul 2002, s. 43; SARI, 154; ŞIPKA, s. 99; ZEYTIN, s. 102 vd.; Yargitay 2. Hukuk Dairesi, T. 1.11.2006, E. 2006/6845 K. 2006/14701; Yargitay 8. Hukuk Dairesi, T. 15.6.2010, E. 2010/2273 K. 2010/3293.

${ }^{56}$ ACABEY, s. 506; ACAR, s. 213 vd.; GÜMÜŞ, s. 259 vd.; HAUSHEER, Heinz/AEBIMÜLLER, Regina E., in Basler Kommentar - ZGB I, Honsell, Heinrich/Vogt, Nedim, Peter/GEISER, Thomas (ed.), 5. Bask1, Helbing Lichtenhahn Verlag, Basel 2014, Art. 197 ZGB pn. 20 vd.; HAUSHEER, Heinz/Reusser, Ruth/GEISER, Thomas, in Berner Kommentar Band II, Stämpfli Verlag, Bern 1992, Art. 197 ZGB pn. 70 vd.; KILIÇOĞLU, Katkı-Katılma Alacağı, s. 128; MUZAFFER, Şeker, Die im Laufe der Zeit, begründet auf gesellschaftliche und kulturelle Besonderheiten, entstandenen und noch entstehenden unterschiedlichen Interpretationen zwischen der schweizerischen und türkischen Lehre in Bezug auf den gesetzlichen Güterstand der Errungenschaftsbeteiligung, Annales 2007, s. 347-362, s. 349 vd.; NUSPLIGER, Art. 197 ZGB pn. 6; JUNGO, Art. 197 ZGB pn. 19 vd.; SARI, s. 154 vd.; STECK, Art. 197 ZGB pn. 26; ŞIPKA, s. 98; ZEYTIN, 104.

${ }^{57}$ HAUSHEER/REUSSER/GEISER, Art. 197 ZGB pn. 54; JUNGO, Art. 197 ZGB pn. 10. 
mümkün değildir. Aksi takdirde boşanan eş belki hiç sahip olmayacağı bir meblağı hakkaniyete aykırı olarak borçlanmış olacaktır. Bu sebeple emeklilik sigortasındaki birikimler ve dayanağı kural olarak bu birikimler olan emeklilik maaşı, maluliyet aylığı, işsizlik parası vb. ödemeler kanunlarca öngörülen yaş sınırına veya riskin gerçekleşmesine kadar belirsiz bir niteliğe sahip oldukları ve tasfiye anında hesaplanabilir olmadıkları için edinilmiş mal sayılmamaktadır ${ }^{58}$. Ancak eşlerin emekliliklerine ilişkin yapılacak olan bir toptan ödemeye mal rejimi devam ederken hak kazanmalarına rağmen mal rejimi sona erdikten sonra ödemenin yapılacak olması söz konusu bu ödemenin TMK m. 219/II-b.2 ZGB m. 197/II-b.2 kapsamında edinilmiş mal sayılabilmesini engellememektedir. Zira eşlerin sosyal güvenlik kurumlarının yapacağı ödemeye mal rejimi devam ederken hak kazanması yeterli olup, ödemenin tasfiyenin yapılmasından sonra gerçekleşmesinin bir önemi yoktur. Burada önemli olan, hakkın kazanıldığı an ve sonra yapılan ödemenin yasal mal rejimine ilişkin döneme ait olmasıdır ${ }^{59}$.

Ödeme, mal rejimi devam ederken toptan yapılmış ise TMK m. 228/II - ZGB m. 207/II'ye göre, yapılan bu ödemelerin hepsi edinilmiş mal sayılmamaktadır. Toptan ödeme veya tazminat yerine ömür boyunca irat bağlanmış olsaydı, mal rejiminin sona erdiği tarihte bundan sonraki döneme ait iradın peşin sermayeye çevrilmiş değeri ne olacak idiyse, tasfiyede o miktarda kişisel mal olarak hesaba katılacak, geriye kalan kısım ise edinilmiş mal olarak kabul edilebilecektir ${ }^{60}$.

Sosyal güvenlik kurumlarının mal rejiminden önce yaptıkları emekliliğe ilişkin ödemelere ilişkin Türk hukuk doktrininde ikili bir ayrım yapılmaktadır. Buna göre mal rejiminden önce sermaye olarak yapılmış ödemeler tüketilmişse kişisel mal sayılacaktır. Ancak mal rejiminden önce

${ }^{58}$ ACABEY, s. 506; ACAR, s. 214; DEMİR, Şamil, Edinilmiş Mallara Katılma Rejiminde Artık Değerin Hesaplanması ve Paylaştırılması, Ankara Barosu Dergisi, 1, 2014, s. 251; GÜMÜŞ, s. 258; HAUSHEER/AEBI-MÜLLER, Art. 197 ZGB pn. 17; HAUSHEER/REUSSER/GEISER, Art. 197 ZGB pn. 54; JUNGO, Art. 197 ZGB pn. 13; KARAMERCAN, Fatih, Katkı - Değer Artış Payı \& Katılma Alacağı Davaları, 3. Baskı, Seçkin Yayıncılık, Ankara 2016, s. 42 vd.; SARI, s. 151; STECK, Art. 197 ZGB pn. 21; ŞIPKA, s. 99; ZEYTIN, 104 vd.; Yargıtay 8. Hukuk Dairesi, T. 13.12.2011, E. 2011/5910 K. 2011/6967; BGE 123 III 289.

${ }^{59}$ ACABEY, s. 522 vd.; ŞIPKA, s. 98; ZEYTIN, 104.

${ }^{60}$ JUNGO, Art. 197 ZGB pn. 12; KILIÇOĞLU, Edinilmiş Mallara Katilma Rejimi, s. 47 vd.; KILIÇOĞLU, Katkı-Katılma Alacağı, s. 133 vd. 
sermaye olarak yapılmış ödemeler henüz tüketilmemişse TMK m. 228/II'deki şekliyle bir hesaplama yapılarak mal rejiminden önceki döneme ilişkin kısım kişisel mal, mal rejiminin devam ettiği döneme ilişkin ödemeler ise edilmiş mal olarak kabul edilecektir. Mal rejiminin başlangıcından önce başlanmış olan irat şeklindeki ödemeler, mal rejiminin devamı süresine tekabül eden kısmı itibariyle edinilmiş mal sayılır. Zira çalışma gücünün kaybolması halinde yapılan bu ödemeler mal rejiminden önce gerçekleşmiş olsa dahi çalışma gücünün telafisine yöneliktir ve etkisini mal rejimi süresince de göstermektedir ${ }^{61}$.

Doktrinde yapılan ikili bu ayrım ve sonuçları edinilmiş mallara katılma rejimi bir bütün olarak ele alındığında belli başlı noktalarda yerinde gözükmemektedir ${ }^{62}$. TMK m. 219/I bir malın edinilmiş mal sayılabilmesi için mal rejiminin devamı süresince karşıllğı verilerek elde edilmesi şartını aramıştır. Ayrıca elde edilen mallar TMK m. 220'ye göre kişisel mal sayılmamalıdır. TMK m. 220/b. 2'de açıkça öngörüldüğü üzere "mal rejiminin başlangıcinda eşlerden birine ait bulunan veya bir eşin sonradan miras yoluyla ya da herhangi bir şekilde karşılıksız kazanma yoluyla elde ettiği malvarlığ değerleri" kişisel mal sayılacaktır ve tasfiye sırasında paylaşmanın konusunu oluşturmayacaklardır. Bu sebeple sosyal güvenlik kurumlarının yaptıkları ödemelerin hangilerinin edilmiş mal sayılacağını tespit ederken TMK'nın sistematiği dikkate alınmalıdır. Buna göre, edinilmiş mallara katılma rejiminin başlangıcından önce sosyal güvenlik kurumlarınca sermaye şeklinde eşlerden birine yapılan ödemeler kişisel mal sayılacaktır. Bu malların mal rejiminin başlamasından önce tüketilmesinin veya tüketilmemesinin söz konusu ödeminin edilmiş mal olarak nitelendirilmesi üzerinde bir etkisinin olmaması gereklidir. Zira TMK m. 220/b. 2 mal rejiminin başlangıcında eşlerden birine ait bulunan her türlü malı mal rejimi başladıktan sonra kişinin mal varlığında bulunup bulunmamasına bakmaksızın açı bir şekilde kişisel mal sayılmaktadır. Ancak mal rejiminden önce sermaye şeklinde yapılmış olan ödemeler tüketilmemiş ve bu ödemelerden mal rejiminin devamı süresince faiz vb. gelirler elde ediliyorsa söz konusu bu gelirler TMK m. 219/II-b.4'e göre kişisel malların geliri olarak edinilmiş mal sayılabilecektir.

\footnotetext{
${ }^{61}$ SARI, s. 149 vd.; ZEYTİN, s. 105.

${ }^{62}$ Karş. ŞIPKA, s. 98.
} 
Sosyal güvenlik kurumlarının yaptı̆̆ emeklilik ödemelerinin dayanağını teşkil eden primlerin kişinin edinilmiş mallarından veya kişisel mallarından karşılanmasının, emekliliğe ilişkin yapılan ödemelerin edinilmiş mal olarak nitelendirmesine bir etkisinin söz konusu olmayacağ 1 doktrinde ve yarg1 kararlarında kabul edilmektedir. Zira TMK m. 219/IIb. 2 - ZGB m. 197/II-b.2 açık bir şekilde sosyal güvenlik kurumlarının yaptığ 1 ödemeleri, edinilmiş mal olarak kabul etmiştir. Kanun koyucu, emeklilik sebebi ile yapılacak ödemelerin edinilmiş mal sayılması için söz konusu ödemelerin dayanağını oluşturan emeklilik primlerinin eşlerin hangi mal grubundan kaynaklanması gerektiğine ilişkin bir ayrım yapmamıştır. $\mathrm{Bu}$ sebeple emeklilik primlerinin kısmen veya tamamen kişisel mallardan karşılanmış olması durumunda dahi yapılacak emeklilik ödemeleri edinilmiş mal sayılacak; TMK m. 220/II-b.4 - ZGB m. 198/IIb.4'e göre kişisel mal yerine geçen değer sayılmayacaktır. Kanun koyucu böylece kişisel mal yerine geçen değerin kişisel mal sayılacağına yönelik öngördüğü ikame ilkesine bir istisna getirmiştir ${ }^{63}$.

\section{Sonuç}

Evlilik birliğinin boşanma ile sona ermesi durumunda emeklilikten doğan hakların hangi kapsamda ve hangi hükümlere göre talep edilebileceği Türk ve İsviçre hukukunda farklı düzenlemelere tabi tutulmuştur.

Türk ve İsviçre hukukunda mal rejimi süresince edinilmiş olan emeklilik toptan ödemeleri veya mal rejimin tasfiyesi esnasında mal varlığında yer alan emeklilik maaşları edinilmiş mal olarak tasfiye hesabına dâhil edilebilecektir. Ancak gelecekte ödenecek emeklilik maaşı, emeklilik ikramiyesi, kıdem tazminatı, maluliyet aylığı, işsizlik parası vb. ve bu ödemelerin dayanağını teşkil eden emeklilik sigortasındaki birikimler edinilmiş mal kabul edilemeyecektir. Zira bu durumda sosyal güvenlik kurumlarınca yapılmış ödemeler ve dolayısıyla mal rejiminin devamı sırasında elde edilmiş bir malvarlığı bulunmamakta olup sadece ileride elde edilme ihtimali bulunan beklemece haklar söz konusudur.

${ }^{63}$ ACABEY, s. 505; ACAR, s. 213 vd.; GÜMÜŞ, s. 258; HAUSHEER/AEBI-MÜLLER, Art. 197 ZGB pn. 17; HAUSHEER/REUSSER/GEISER, Art. 197 ZGB pn. 53 vd.; JUNGO, Art. 197 ZGB pn. 12; NUSPLIGER, Art. 197 ZGB pn. 6; SARI, s. 152; STECK, Art. 197 ZGB pn. 19; ZEYTIN, s. 102-103; BGE 118 II 382, 387, E. 4b. aa; BGE 123 III 442 vd., E. 2 d. 
İsviçre hukuku, yukarıda açıklandığı üzere, Türk hukukundan farklı olarak evlilik birliğinin boşanma ile sonuçlanması halinde eşlere, aralarında geçerli olan mal rejiminden bağımsız olarak emeklilik sigortasındaki birikimlerin (çıkış ödeneklerinin) veya emeklilik maaşlarının paylaşılması imkânını tanımıştır. İsviçre hukukunda eleştiriye açık olan en önemli husus, eşlerden birinin boşanmaya ağır kusuru ile sebep olmasına rağmen kusursuz veya daha az kusurlu eşin emeklilikten doğan hakları üzerinde talepte bulunabilmesidir. Oysaki eşlerden birinin zina, hayata kast veya pek kötü davranış gibi sebeplerle boşanmaya sebep olması ve buna rağmen diğer eşin emeklilik haklarından boşandıktan sonra pay sahibi olabilmesi hakkaniyete uygun bir çözüm olarak gözükmemektedir.

Genel olarak İsviçre hukukundaki bir düzenlemenin Türk hukukunda mevcut olmaması, zamanının önemli bir kısmını ailesine ayıran ve dolayısıyla çalışamayan ya da çalışmak için yeterince zaman ayıramayan eşin boşanma sonrasında diğer eşe göre daha zayıf konumda kalmasına sebep olmaktadır. Zira çalışan eş, mal rejimi sırasında maaşından yapılan kesintilerin birikimi sonucu belirli şartların gerçekleşmesi ile emeklilik maaşı almayı hak edebilirken diğer eş ya bu haktan mahrum olmakta ya da zamanın asıl kısmını ailesine ayırması sebebi ile daha az çalışmakta ve emekliliğe yönelik daha az hak elde etmektedir. Her ne kadar TMK m. 175'e göre boşanma yüzünden yoksulluğa düssecek tarafin yoksulluk nafakası talep etme hakkı olsa da nafaka yükümlüsü eşin ölmesi durumunda TMK m. 176/III'e göre irat şeklinde ödenmesine karar verilen nafaka kendiliğinden kalkacak ve nafaka alacaklısı eş maddi bakımdan zor duruma düşecektir. Eşlere birbirlerinin hayatta kalmalarından bağımsız olarak emeklilik maaşları üzerinde hak tanınması halinde söz konusu bu mağduriyetlerin yaşanması asgariye indirilmiş olacaktır.

$\mathrm{Bu}$ sebepler göz önünde bulundurulduğu takdirde TMK ve sosyal güvenlik mevzuatımızda da İsviçre hukukunda olduğu gibi, evlilik birliğinin boşanma ile sona ermesi durumunda eşlerin emeklilikten doğan haklarının paylaşılmasına yönelik düzenlemelerin yapılması yerinde olacaktır. 


\section{TABLO}

Schätzung des ehelichen Teils einer Altersrente, in Prozent

Alter bei Rentenbeginn

(Yaşlılık Aylığından Eşlerin Paylarına Düşecek Tahmini Değerler, Yüzde Olarak) (Emekliliğin Başlangıcındaki Yaş)

\begin{tabular}{|c|c|c|c|c|c|c|c|c|c|c|c|c|c|}
\hline Heirat & 58 & 59 & 60 & 61 & 62 & 63 & 64 & 65 & 66 & 67 & 68 & 69 & 70 \\
\hline$\leq 25$ & 100.0 & 100.0 & 100.0 & 100.0 & 100.0 & 100.0 & 100.0 & 100.0 & 100.0 & 100.0 & 100.0 & 100.0 & 100.0 \\
\hline 26 & 98.1 & 98.2 & 98.3 & 98.4 & 98.4 & 98.5 & 98.5 & 98.6 & 98.6 & 98.7 & 98.7 & 98.8 & 98.8 \\
\hline 27 & 96.3 & 96.4 & 96.6 & 96.7 & 96.9 & 97.0 & 97.1 & 97.2 & 97.3 & 97.4 & 97.5 & 97.6 & 97.6 \\
\hline 28 & 94.4 & 94.6 & 94.9 & 95.1 & 95.3 & 95.5 & 95.6 & 95.8 & 95.9 & 96.1 & 96.2 & 96.3 & 96.4 \\
\hline 29 & 92.5 & 92.9 & 93.2 & 93.5 & 93.7 & 94.0 & 94.2 & 94.4 & 94.6 & 94.8 & 94.9 & 95.1 & 953 \\
\hline 30 & 90.6 & 91.1 & 91.5 & 91.8 & 92.2 & 92.5 & 92.7 & 93.0 & 93.2 & 93.5 & 93.7 & 93.9 & 94.1 \\
\hline 31 & 88.8 & 89.3 & 89.8 & 90.2 & 90.6 & 90.9 & 91.3 & 91.6 & 91.9 & 92.2 & 92.4 & 92.7 & 92.9 \\
\hline 32 & 86.9 & 87.5 & 88.0 & 88.6 & 89.0 & 89.4 & 89.8 & 90.2 & 90.5 & 90.9 & 91.2 & 91.4 & 91.7 \\
\hline 33 & 85.0 & 85.7 & 86.3 & 86.9 & 87.4 & 87.9 & 88.4 & 88.8 & $89 \ldots 2$ & 89.6 & 89.9 & 90.2 & 90.5 \\
\hline 34 & 83.2 & 83.9 & 84.6 & 85.3 & 85.9 & 86.4 & 86.9 & 87.4 & 87.8 & 88.2 & 88.6 & 89.0 & 89.3 \\
\hline 35 & 81.3 & 82.1 & 82.9 & 83.6 & 84.3 & 84.9 & 85.5 & 86.0 & 86.5 & 86.9 & 87.4 & 87.8 & 88.1 \\
\hline 36 & 78.6 & 79.6 & 80.5 & 81.3 & 82.1 & 82.8 & 83.4 & 84.0 & 84.6 & 85.1 & 85.6 & 86.0 & 86.4 \\
\hline 37 & 75.9 & 77.0 & 78.0 & 79.0 & 79.8 & 80.6 & $81-3$ & 82.0 & 82.6 & 83.2 & 83.8 & 84.3 & 84.7 \\
\hline 38 & 73.3 & 74.5 & 75.6 & 76.6 & 77.6 & 78.4 & 79.3 & 80.0 & 80.7 & 81.3 & 81.9 & 82.5 & 83.1 \\
\hline 39 & 70.6 & 71.9 & 73.2 & 74.3 & 75.3 & 76.3 & 77.2 & 78.0 & 78.8 & 79.5 & 80.1 & 80.8 & 81.4 \\
\hline 40 & 67.9 & 69.4 & 70.7 & 32.0 & 73.1 & 74.1 & 75.1 & 76.0 & 76.8 & 77.6 & 78.3 & 79.0 & 79.7 \\
\hline 41 & 65.2 & 66.8 & 68.3 & 69.6 & 70.9 & 72.0 & 73.0 & 74.0 & 74.9 & 75.7 & 76.5 & 77.3 & 78.0 \\
\hline 42 & 62.6 & 64.3 & 65.9 & 67.3 & 68.6 & 69.8 & 71.0 & 72.0 & 73.0 & 73.9 & 74.7 & 75.5 & 76.3 \\
\hline 43 & 59.9 & 61.7 & 63.4 & 65.0 & 66.4 & 67.7 & 68.9 & 70.0 & 71.0 & 72.0 & 72.9 & 73.8 & 74.6 \\
\hline 44 & 57.2 & 59.2 & 61.0 & 62.6 & 64.1 & 65.5 & 66.8 & 68.0 & 69.1 & 70.1 & 71.1 & 72.0 & 72.9 \\
\hline 45 & 54.5 & 56.6 & 58.5 & 60.3 & 61.9 & 63.4 & 64.7 & 66.0 & 67.2 & 68.3 & 69.3 & 70.3 & 71.2 \\
\hline 46 & so.s & 52.8 & 54.9 & 56.8 & 58.5 & 60.1 & 61.6 & 63.0 & 64.3 & 65.5 & 66.6 & 67.7 & 68.6 \\
\hline 47 & 46.5 & 49.0 & 51.2 & 53.3 & 55.2 & 56.9 & 58.5 & 60.0 & 61.4 & 62.7 & 63.9 & 65.0 & 66.1 \\
\hline 48 & 42.5 & 45.2 & 47.6 & 49.8 & 51.8 & 53.7 & 55.4 & 57.0 & 58.5 & 59.9 & 612 & 62.4 & 63.6 \\
\hline 49 & 38.5 & 41.3 & 43.9 & 46.3 & 48.4 & 50.4 & 52.3 & 54.0 & 55.6 & 57.1 & 58.5 & 59.8 & 61.0 \\
\hline so & 34.5 & 37.5 & 40.2 & 42.8 & 45.1 & 47.2 & 49.2 & 51.0 & 52.7 & 54.3 & 55.8 & 57.2 & 58.5 \\
\hline 51 & 30.5 & 33.7 & 36.6 & 39.3 & 41.7 & 44.0 & 46.1 & 48.0 & 49.8 & 51.5 & 53.1 & 54.5 & 55.9 \\
\hline 52 & 26.5 & 29.8 & 32.9 & 35.7 & 38.3 & 40.7 & 42.9 & 45.0 & 46.9 & 48.7 & 50.4 & 51.9 & 53.4 \\
\hline 53 & 22.5 & 26.0 & 29.3 & 32.2 & 35.0 & 37.5 & 39.8 & 42.0 & 44.0 & 45.9 & 47.7 & 49.3 & 50.8 \\
\hline 54 & 18.4 & 22.2 & 25.6 & 28.7 & 31.6 & 34.3 & 36.7 & 39.0 & 41.1 & 43.1 & 44.9 & 46.7 & 48.3 \\
\hline 55 & 14.4 & 18.4 & 22.0 & 25.2 & 28.3 & 31.0 & 33.6 & 36.0 & 38.2 & 40.3 & 42.2 & 44.1 & 45.8 \\
\hline 56 & 9.6 & 13.8 & 17.6 & 21.0 & 24.2 & 27.2 & 29.9 & 32.4 & 34.7 & 36.9 & 39.0 & 40.9 & 42.7 \\
\hline 57 & 4.8 & 9.2 & 13.2 & 16.8 & 20.2 & 23.3 & 26.1 & 28.8 & 31.3 & 33.6 & 35.7 & 37.8 & 39.7 \\
\hline 58 & & 4.6 & 8.8 & 12.6 & 16.1 & 19.4 & 22.4 & 25.2 & 27.8 & 30.2 & 32.5 & 34.6 & 36.6 \\
\hline 59 & & & 4.4 & 8.4 & 12.1 & 15.5 & 18.7 & 21.6 & 24.3 & 26.9 & 29.2 & 31.5 & 33.6 \\
\hline 60 & & & & 4.2 & 8.1 & 11.6 & 14.9 & 18.0 & 20.8 & 23.5 & 26.0 & 28.3 & 30.5 \\
\hline 61 & & & & & 4.0 & 7.8 & 11.2 & 14.4 & 17.4 & 20.1 & 22.7 & 25.2 & 27.5 \\
\hline 62 & & & & & & 3.9 & 7.5 & 10.8 & 13.9 & 16.8 & 19.5 & 22.0 & 24.4 \\
\hline 63 & & & & & & & 3.7 & 7.2 & 10.4 & 13.4 & 16.2 & 18.9 & 21.4 \\
\hline 64 & & & & & & & & 3.6 & 6.9 & 10.1 & 13.0 & 15.7 & 18.3 \\
\hline 65 & & & & & & & & & 3.5 & 6.7 & 9.7 & 12.6 & 15.3 \\
\hline 66 & & & & & & & & & & 3.4 & 6.5 & 9.4 & 12.2 \\
\hline 67 & & & & & & & & & & & 3.2 & 6.3 & 92 \\
\hline 68 & & & & & & & & & & & & 3.1 & 6.1 \\
\hline 69 & & & & & & & & & & & & & 3.1 \\
\hline
\end{tabular}

\section{KAYNAKÇA}

ACABEY, Mehmet Beşir: "Edinilmiş Mallara Katılma Rejiminde Mal Grupları-İspat Kuralları ve Eşlerden Paylı Mülkiyeti Altındaki Mallara İlişkin Düzenlemeler", Dokuz Eylül Üniversitesi Hukuk Fakültesi Dergisi, 9, 2007, s. 491-534.

ACAR, Faruk: $\quad$ Aile Hukukumuzda Aile Konutu Mal Rejimleri ve Eşin Yasal Miras Pay1, 3. Bask1, Seçkin Yayıncılık, Ankara 2016.

CEYLAN, Ebru: Türk ve İsviçre Hukukunda Boşanmanın Hukuki Sonuçları, Galatasaray Üniversitesi Yayınları, İstanbul 2006.

DEMIR, Şamil: Edinilmiş Mallara Katılma Rejiminde Artık Değerin Hesaplanması ve Paylaştırılması, Ankara Barosu Dergisi, 1, 2014, s. 247-269. 
GEIGER, Ingrid Katharina/MICHAELIS, Bettina/PIFKO, Clarisse: Grundlagen der Sozialversicherungen in der Schweiz, 3. Bask1, Compendio Bildungsmedien, Zürich 2012.

GEISER, Thomas: Scheidung und das Recht der beruflichen Vorsorge Was bringt das neue Recht?, AJP/PJA 10/2015, s. 1371-1386.

GEISER, Thomas: Gestaltungsmöglichkeiten beim Vorsorgeausgleich, Zeitschrift des Bernischen Juristenvereins. - Bern. - Jg. 153, 2017, H. 1, S. 1-24.

GÜMÜŞ, Mustafa Alper:Teori ve Uygulamada Evliliğin Genel Hükümleri ve Mal Rejimleri (TMK m. 185 - 281), Vedat Kitapçılık, İstanbul 2008.

GRÜTTER, Myriam: Der neue Vorsorgeausgleich im Überblick, FamPra.ch, 2017, S. 127, s. $127-156$.

HAUSHEER, Heinz/AEBI-MÜLLER, Regina E.:Basler Kommentar - ZGB I, Honsell, Heinrich/Vogt, Nedim Peter/Geiser, Thomas (ed.), 5. Bask1, Helbing Lichtenhahn Verlag, Basel 2014.

HAUSHEER, Heinz/GEISER, Thomas/AEBI-MÜLLER, Regina E.:Das Familienrecht des Schweizerischen Zivilgesetzbuches, 5. Bask1, Stämpfli Verlag, Bern 2014.

HAUSHEER, Heinz/REUSSER, Ruth/GEISER, Thomas: Berner Kommentar Band II, Stämpfli Verlag, Bern 1992.

KARAMERCAN, Fatih: Katkı - Değer Artış Payı \& Katılma Alacağı Davaları, 3. Bask1, Seçkin Yayıncılık, Ankara 2016.

KILIÇOĞLU, Ahmet M.: Edinilmiş Mallara Katilma Rejimi (Tartışmalar-Örnekli Açıklamalar-Formüller-Tablolar-İlgili Yasa Metinleri), 2. Bask1, Turhan Kitabevi, İstanbul 2002.

KILIÇOĞLU, Ahmet M.: Katkı-Katılma Alacağı, 5. Baskı, Turhan Kitabevi, Ankara 2014. KILIÇOĞLU, Ahmet M.: Aile Hukuku, 2. Baskı, Turhan Kitabevi, İstanbul 2016.

MUZAFFER, Şeker: Die im Laufe der Zeit, begründet auf gesellschaftliche und kulturelle Besonderheiten, entstandenen und noch entstehenden unterschiedlichen Interpretationen zwischen der schweizerischen und türkischen Lehre in Bezug auf den gesetzlichen Güterstand der Errungenschaftsbeteiligung, Annales 2007, s. 347-362.

NUSPLIGER, Isabelle: ZGB Kommentar Schweizerisches Zivilgesetzbuch, Kostkiewicz, Jolanta Kren/Wolf, Stephan/Amstutz, Marc/Fankhauser, Roland (ed.), Orell Füssli Verlag, 3. Bask1, Zürich 2016.

JUNGO, Alexandra: CHK - Handkommentar zum Schweizer Privatrecht - Personen- und Familienrecht - Partnerschaftsgesetz, Breitschmid, Peter/Jungo, Alexandra (ed.), 3. Bask1, Schulthess Verlag, Zürich 2016.

SARI, Suat: $\quad$ Evlilik Birliğinde Yasal Mal Rejimi Olarak Edinilmiş Mallara Katılma Rejimi, Beşir Kitabevi, İstanbul 2017.

SCHWANDER, Ivo: ZGB Kommentar Schweizerisches Zivilgesetzbuch, Kostkiewicz, Jolanta Kren/Wolf, Stephan/Amstutz, Marc/Fankhauser, Roland (ed.), 3. Bask1, Orell Füssli Verlag, Zürich 2016.

SCHWENZER, Ingeborg/BÜCHLER, Andrea Famkomm - Scheidung Band I: ZGB, Schwenzer, Ingeborg/Fankhauser, Roland (ed.), 3. Bask1, Stämpfli Verlag, Zürih 2017. 
ŞIPKA, Şükran: Türk Hukukunda Edinilmiş Mallara Katılma Rejimi, 3. Baksı, On İki Levha Yayınc1lık, İstanbul 2013.

STECK, Daniel: FamKomm - Scheidung Band I: ZGB, Ingeborg, Schwenzer/Roland, Fankhauser (ed.), 3. Bask1, Stämpfli Verlag, Bern 2017.

ZEYTIN, Zafer: Edinilmiş Mallara Katılma Rejimi ve Tasfiyesi, 2. Baskı, Seçkin Yayınc1lık, Ankara 2008. 
